\section{ГИДРОТЕРМАЛЬНАЯ ПРИРОДА КАВЕРНООБРАЗОВАНИЯ ВЕНД-РИФЕЙСКИХ КОЛЛЕКТОРОВ БАЙКИТСКОЙ АНТЕКЛИЗЫ - КЛЮЧ К ПРОГНОЗУ ЗОН НЕФТЕГАЗОНАКОПЛЕНИЯ}

\author{
А.Д. Коробов 1 , Л.А. Коробова² \\ Саратовский государственный университет, \\ 1 кафедра петрографии и минералогии \\ 2 кафедра геологии и геохимии горючих ископаемых \\ E-mail: korobov@sgu.ru
}

\begin{abstract}
Формирование единого венд-рифрейского резервуара ЮрубченоТохомской зоны (ЮТЗ) Сибирской платформы произошло в результате гидротермальной активности. Прогноз перспективных на УВ площадей в венд-рифейских отложениях ЮТЗ базируется на выявлении зон гидротермальной деятельности, приведшей к появлению каверн и пор в трещиноватых карбонатных толщах. Минералами-индикаторами нефтегазонасыщенных доломитов являются анкериты, ассоциирующие с кварцем.
\end{abstract}

Hydrothermal Nature of Cavern Formation in the VendianRiphean Collectors in the Baikitskaya Anteclise - a Key to Predicting Zones of Oil and Gas Accumulation

\section{A.D. Korobov, L.A. Korobova}

The joint Vendian-Riphean reservoir in the Yurubcheno-Tokhomskaya zone (YuTZ) of the Siberian Platform has resulted from hydrothermal activity. Prediction of the HC-prospective fields in the VendianRuphean deposits is based on revealing the zones of hydrothermal activity conductive to cavern and pore formation in the fractured carbonate series. Quartz-associated ankerites are indicator minerals for oil- and gas-saturated dolomites.

\section{Введение}

Гигантская Юрубчено-Тохомская зона (ЮТЗ) нефтезагонакопления на юго-западе Сибирской платформы содержит уникальные запасы углеводородов (УВ) в основном в рифейских отложениях. Полученная в ходе изучения этой зоны и прилегающих территорий геолого-геофизическая информация позволяет судить о высоком нефтегазовом потенциале рифейских образований региона, занимающего огромное пространство приенисейской части Восточной Сибири (почти на всём протяжении с юга на север p. Енисей).

В тектоническом отношении ЮТЗ, как и входящие в её состав Куюмбинская, Юрубченская, Оморинская площади, приурочена к Камовскому своду Байкитской антеклизы, осадочный чехол которой сложен верхнепротерозойскими и нижнепалеозойскими отложениями и разделяется на рифейский и венднижнепалеозойский структурные этажи. Рифейские образования представлены мощными карбонатными, терригенно-карбонатными и карбонатно-терригенными толщами общей мощностью предположительно до 4,5 км. На рифейских комплексах с размывом залегают вендские образования, перекрытые кембрийскими отложениями. Особого внимания среди последних заслуживают породы соленосной усольской свиты, считающиеся мощным региональным флюидоупором Байкитской антеклизы $[1,2]$.

Суть господствующей до настоящего времени геологической модели ЮТЗ заключается в идее выклинивания разновозрастных, литологически и фациально однородных рифейских толщ под эрозионную поверхность рифея [3]. При этом утверждается, что под эрозионной поверхностью рифея практически во всех карбонатных толщах Байкитской антеклизы, выходящих на предвендскую поверхность и образующих под этой поверхностью единый резервуар, располагается гигантская массивная нефтяная залежь. Появление такого резервуара обусловлено распространением на огромной территории высокоемкого каверново-трещинного коллектора [4]. С учётом этих представлений прогнозировалось обнаружение неантиклинальных залежей УВ в глубокозалегающих карбонатных горизонтах рифея и в терригенных отложениях венда на южной границе зоны. 
Практика геолого-разведочных работ показала неадекватность этой модели реальной геологической обстановке ЮТЗ, главным образом её Куюмбинского участка. Поэтому разведка месторождений была проведена крайне неудачно - из 20 пробуренных скважин только 4 дали промышленные притоки УВ [5]. В ходе работ были получены новые данные [2, 6-8], свидетельствующие о том, что наилучшие нефтегазонасыщенные коллекторы Куюмбинского участка приурочены к линейно-очаговым (не региональным!) зонам аномальной трещиноватости. Характерно, что эти зоны не ограничиваются поверхностью несогласия, разделяющей рифейские и вендские образования, а напротив, слагают единый венд-рифейский резервуар. Продуктивная часть коллекторов таких резервуаров представлена доломитами, эффективный объём пустот которых обеспечен интенсивно развитыми вертикальными и субгоризонтальными трещинами. Причём наиболее типичной особенностью таких трещин является развитие по ним каверн выщелачивания. Учитывая в целом широкое площадное распространение трещиноватости в карбонатных породах [4], одним из необходимых и важнейших условий возникновения УВ в рифей-вендских коллекторах ЮТЗ, на наш взгляд, является наличие в доломитах каверн (кавернозности).

Природа кавернозности нефтегазонасыщенных доломитов ЮТЗ остаётся до конца не понятой. Абсолютное большинство геологов вслед за А.Э.Конторовичем и В.С.Сурковым с коллегами $[1,4,9,10]$ считают её порождением гипергенных явлений. По мнению вышеуказанных исследователей, длительный предвендский континентальный перерыв сопровождался развитием процессов карстообразования и кавернообразования вдоль существовавших трещин. Это способствовало формированию пористых проницаемых пород в верхней части рифейского разреза, выведенных на предвендскую дневную поверхность.

С данным положением трудно не согласиться. Вместе с тем нельзя забывать, что карбонатные породы являются чрезвычайно чувствительными ко всякого рода изменениям физико-химических и термобарических условий. Они особенно интенсивно подвер- гаются процессам вторичного преобразования (растворению, перекристаллизации, метасоматическому замещению) под действием растворов различной природы, в том числе циркулирующих на глубине. Следовательно, сообразно теоретическим представлениям Р.С.Сахибгареева [11], будучи в дальнейшем погруженными, карбонатные породы, не дойдя ещё до главной зоны нефтеобразования (2000 м), могут в значительной степени измениться и во многом (если не полностью) потерять приобретённый в гипергенных условиях коллекторский потенциал. Скорее всего, так и произошло на территории ЮТЗ, поскольку зоны нефтегазонасыщения в вендрифейском разрезе носят локальный (очаговый) характер [7, 8]. Учитывая наблюдения Е.М.Арабаджи и П.Н.Страхова [12] за этапностью формирования пор и каверн в погребённых карбонатных отложениях, надо говорить о пустотном пространстве новой генерации, возникшем на глубине на границе двух структурных этажей: в кровельной части рифейской и в основании несогласно перекрывающей вендской карбонатных толщ.

Справедливость такого заключения подтверждают наши исследования [13], проведённые в Западной Сибири. Они, в частности, показали, что в условиях тектоногидротермальной активизации ископаемого континентального рифта карбонатные толщи фундамента и непосредственно залегающие на нём терригенные породы чехла испытывали процессы растворения, выщелачивания (кавернообразования), перекристаллизации и доломитизации. Такие преобразования были наиболее значительными на контакте «фундамент-чехол» и вызывались горячими ресургентными растворами, возникавшими при смешении восходящих нагретых вод рифтовых мегапрогибов и нисходящих - осадочного чехла. Эти же растворы ответственны за миграцию УВ и заполнение коллектора жидкой нефтью. Поэтому, по аналогии с Западной Сибирью, рассмотрение причин формирования вторичных трещино-каверновых коллекторов венд-рифейского комплекса ЮТЗ необходимо связывать с гидротермальной деятельностью, сопровождавшей периоды тектоно-магматической активизации Сибирской платформы. Это согласуется с выводом В.В. Харахинова и его соавторов [7] о 
том, что возникновение флюидодинамических режимов ЮТЗ происходило в триасе и было вызвано тектонической активизацией земной коры. Такой подход позволит с принципиально новых позиций взглянуть на природу резервуаров и прогноз нефтегазоносности Юрубчено-Тохомской зоны, размещённой на территории Байкитской антеклизы.

\section{Минеральные преобразования, сопровождающие перекристаллизацию и кавернообразование доломитов}

Промышленная газонефтеносность рифейского разреза ЮТЗ связана с аладьинской свитой [3] или, по А.М.Пустыльникову и Л.Г.Вакуленко [14], с юрубченской (аналог шиктинская) и чавичинской (аналог юктенская) толщами. Продуктивные горизонты на Юрубченской, Оморинской, Ковинской и Верхнетайгинской площадях сложены белыми, светло-серыми, розоватыми, кирпичнокрасными и сургучного цвета перекристаллизованными мелко-среднекристаллическими доломитами и анкеритами с включением извилистых прослоев и гнёзд вишнёвокрасных, сине-зелёных аргиллитов, чёрных кремнистых прослоев, вторичных крупнокристаллических анкеритов. На Куюмбинской площади образования рассматриваемой группы представлены серыми со светлорозовым, зелёным и коричневым оттенком доломитами. Доломиты средне- и мелкозернистые, волнисто- и линзовидно-слоистые, часто фитогенные (строматолитовые) или органогенно-обломочные, трещиноватые. Интенсивно трещиноватые доломитовые породы продуктивных горизонтов подверглись значительным вторичным преобразованиям: перекристаллизации, кавернообразованию, доломитизации, анкеритизации, окремнению (окварцеванию). Сами трещины и сопряжённые с ними каверны выщелачивания в таких случаях частично или полностью выполнены доломитом, кальцитом, анкеритом, минералами кремнезёма, нафтидами, пиритом [15].

Установлено [2, 3, 14], что органогенные (фитогенные) и органогенно-обломочные доломиты, содержащие минимальное количество терригенного (некарбонатного) материала, сильнее всего подвержены трещинообразованию, перекристаллизации и окремнению (окварцеванию). От этого породы становятся аномально трещиноватыми, подверженными активной деятельности растворов, и как следствие приобретают повышенную плотность распределения каверн выщелачивания, то есть возникает высококачественный трещинно-каверновый коллектор, с которым сопряжены основные запасы углеводородов ЮТЗ.

По мнению некоторых специалистов [8, 14], процессы накопления и перераспределения кремнистого вещества оказали значительное влияние на формирование трещинно-каверновых коллекторов и даже в известной степени определили площадь их распространения. Поэтому, чтобы более надежно прогнозировать зоны нефтегазонакопления ЮТЗ, подробнее остановимся на рассмотрении взаимосвязанных процессов перекристаллизации, кавернообразования, окремнения и других минеральных преобразований в доломитовых породах кровельной части рифейского разреза.

Описание кернового материала и просмотр шлифов свидетельствуют о том, что появление каверн, в различной степени насыщенных битумами, наблюдается, как правило, в доломитовых породах, испытавших перекристаллизацию. В начальной стадии перекристаллизация носит неравномерный пятнистый характер или проявляется в виде разрозненных прожилков. При этом скрытои микрокристаллические агрегаты доломита укрупняются. В процессе перекристаллизации отмечается увеличение межзернового пространства, что сопряжено с появлением пор.

По мере развития процесса поры сечением в десятые доли миллиметра укрупняются и превращаются в каверны размером от 1,0 до 10,0 мм, в редких случаях до 20,0 40,0 мм. Крупные каверны выщелачивания начинают срастаться друг с другом. В зонах максимальной перекристаллизации породы становятся сложенными вторичным крупнокристаллическим (иногда гигантозернистым) анкеритом, приобретают кирпично-красную до сургучной окраску [15] и в некоторых случаях ноздреватую текстуру. Приведенные данные свидетельствуют о том, что перекристаллизация доломитовых пород сопровождается минеральными преобразованиями, а именно появлением анкерита, то есть железистого доломита. 
Эти процессы затрагивают поры, каверны и трещины карбонатных толщ, которые представляют собой единую гидродинамическую систему циркулирующих растворов. В названных пустотах при перекристаллизации вмещающих пород развиваются кварц, халцедон, доломит (редко кальцит), анкерит, ангидрит, пирит (редко халькопирит). В распределении этих минералов при перекристаллизации устанавливается определенная закономерность.

Выделения кремнезема отмечаются уже на участках слабовыраженной неравномерной перекристаллизации доломитов. Они представлены серым и молочно-белым тонко-, реже мелкокристаллическим кварцем, иногда радиально-лучистыми агрегатами халцедона. Эти минералы выполняют поры и микрокаверны, а также отмечаются внутри прослоев скрыто- и микрокристаллических доломитов. Мелкие выделения кремнезема и их скопления в доломите макроскопически не различимы. В шлифах часто видны реликты доломита, замещаемого халцедоном и кварцем. Содержание минералов кремнезема в таких породах может варьировать от 5-10 до $30-40 \%$ [14].

На участках активной перекристаллизации доломита, где появляются крупные каверны, возникают скопления прозрачного или молочно-белого кварца, которые залечивают трещины, секущие доломитовые породы, а также выполняют каверны. В относительно мелких кавернах кварцем сложен либо весь их объём, либо он ассоциирует с крупнокристаллическим доломитом, редко ангидритом. В крупных кавернах кварц инкрустирует стенки, на поверхности его зёрен отмечается сыпь мелких кристаллов пирита. Кварц часто представлен идиоморфными зёрнами длиной до 30-40 мм, образующими друзы. Нередко он ассоциирует с ангидритом [14].

При просмотре керна и шлифов в глаза бросается одно очень важное обстоятельство. Наблюдается приуроченность вторичного наиболее ярко окрашенного за счёт железа коричнево-красного доломита (анкерита [15]) к участкам максимального окварцевания, развитого, прежде всего, по пустотному пространству перекристаллизованных доломитовых пород. Следовательно, по мере на- растания перекристаллизации и окварцевания (окремнения) первичных доломитовых толщ они замещаются анкеритом (железистым доломитом). Этот минерал слагает не только саму перекристаллизованную породу, но и выполняет (инкрустирует) многочисленные каверны, где ассоциирует с друзами кварца.

\section{Обсуждение результатов}

Сделанный вывод о характере гидротермальных изменений карбонатных пород, в толще которых сформировались кварцевые тела и хрустальные гнёзда, удивительным образом перекликается с наблюдениями В.Ю.Эшкина [16]. Он, в частности, установил, что в зоне, непосредственно примыкающей к участкам окварцевания, происходит либо перекристаллизация уже существующего доломита, либо его возникновение за счёт метасоматического замещения первичного кальцита. Но в любом случае новообразованный доломит железистый (содержание $\mathrm{FeCO}_{3}$ достигает 10,0\%). В зонах окисления за счёт образования гидроокислов железа такая порода приобретает бурую (до тёмно-бурой) окраску, что является основным поисковым признаком на хрусталеносные жилы и гнёзда в карбонатных породах [16].

Сказанное дает нам основание сделать три принципиальных вывода. Во-первых, процессы кавернообразования и окварцевания в продуктивных венд-рифейских толщах не были связаны с гипергенными явлениями, обусловленными длительным предвендским континентальным перерывом. Они порождались гидротермальной деятельностью. На это указывают, помимо приведённых рассуждений, прямые термобарические исследования, показавшие [14], что друзы кварца в порах и кавернах перекристаллизованного доломита сформировались при температурах $70-80^{\circ} \mathrm{C}$.

Во-вторых, гидротермальные изменения карбонатных толщ при окварцевании и кавернообразовании носят отчётливо выраженный зональный характер: исходные доломитовые породы $\rightarrow$ перекристаллизованные доломиты $\rightarrow$ анкериты $\rightarrow$ кварцевые тела. Зональность определяется главным образом химическим и минеральным составом первичных пород, а также составом гидротермальных растворов. 
В-третьих, участки максимального окварцевания и перераспределения кремнезёма приурочены к зонам активной циркуляции горячих вод.

Специальные работы, проведенные на месторождениях оптического сырья [16-18], свидетельствуют о том, что огромную роль в процессе хрусталеобразования в карбонатных толщах, наряду с гидротермальной деятельностью, играли многократно возобновляемые тектонические подвижки. Они определяли количество трещин и разнообразие их ориентировки, что, в свою очередь, контролировало степень и масштабы окварцевания карбонатных пород. Всё это реализовалось при внедрении интрузивных тел (гранитов, гранодиоритов) и гидротермальной деятельности, проистекавших в периоды тектономагматической активизации.

Эти же факторы ответственны за становление Юрубчено-Тохомской зоны нефтегазонакопления, и в частности Куюмбинского месторождения. Так, по мнению В.В. Харахинова и его коллег [2], неоднократное тектоническое обновление системы древней довендской трещиноватости имело исключительное значение для формирования коллекторов. Трещинная тектоника наиболее интенсивно себя проявила в триасе и была вызвана активизацией древних сбросово-сдвиговых форм в процессе растяжения земной коры [7].

Общеизвестно, что в конце перми, но главным образом в начале триаса, западная часть Сибирской платформы испытала грандиозную по своим масштабам тектоно-магматическую активизацию, сопровождающуюся колоссальными излияниями базальтовых расплавов. Установлено $[19,20]$, что трапповый магматизм имел значительное влияние на термическое преобразование нефтегазоматеринских отложений, а также на нефтегазонакопление и сохранность скоплений УВ. В этой связи необходимо акцентировать внимание на то, что в районах развития траппов на постмагматической стадии господствовали средне-низкотемпературные гидротермальные процессы. Они были широко распространены и проистекали не только в приповерхностных зонах, но оказывались приуроченными к подводящим каналам базальтовых покровов и межпластовым интру- зиям [21]. Эти гидротермальные процессы порождали флюидодинамические системы, в которых, с одной стороны, происходило переформирование и разрушение залежей, образованных на дотрапповой стадии существования бассейна, а с другой - возникали новые порции УВ, способные мигрировать из нефтематеринских толщ [22].

Сказанное находит подтверждение в выводах В.В.Харахинова и Р.Н. Мухаметзянова и их коллег $[7,8]$ о том, что в ЮТЗ в триасе в условиях сильного растяжения земной коры создавались флюидодинамические режимы, которые формировали в венд-рифейском разрезе очаговые зоны флюидонасыщения. Рассматриваемый флюид, с точки зрения Р.П. Готтих и Б.И. Писоцкого [23], представляет собой систему со сложной парагенетической ассоциацией УВ и многовалентных катионов (Fe, Ti, Y, U), которая обладает определенными чертами сходства с рудными флюидными (гидротермальными) системами. Важно отметить присутствие в горячих растворах железа, которое, скорее всего, находилось в виде $\mathrm{FeHCO}_{3}{ }^{+}$, и кремния. Источником этих элементов и углеводородов были, в первую очередь, осадочные породы.

Миграция гидротерм осуществлялась по дизъюнктивным нарушениям и оперяющим их зонам трещиноватости, которые, находясь в режиме многократно возобновляемых тектонических подвижек, выполняли функцию природных насосов [24]. Обогащённые $\mathrm{Si}, \mathrm{Fe}$ и другими элементами, а также УВ-флюидом нагретые растворы [23] взаимодействовали с вмещающими доломитами в обстановке почти закрытой системы с повышенными температурами. Этому способствовали перекрывающие вендские отложения породы соленосной усольской свиты, выступающие, по мнению В.С. Суркова, В.В. Харахинова и их коллег $[1,2]$, в качестве мощного регионального флюидоупора. По всей видимости, по аналогии с карбонатными толщами фундамента Западно-Сибирской плиты [13, 25], в пределах ЮТЗ близко-одновременно происходили перекристаллизация и анкеритизация доломитов, каверно- и порообразование, окварцевание (окремнение) и насыщение вновь возникающего коллектора жидкой нефтью.

Замещение доломита $\mathrm{CaMg}\left(\mathrm{CO}_{3}\right)_{2}$ анкеритом $\mathrm{Ca}(\mathrm{Fe}, \mathrm{Mg})\left[\mathrm{CO}_{3}\right]_{2}$ осуществлялось за 
счёт присутствующего в горячих растворах $\mathrm{FeHCO}_{3}{ }^{+}$. Наиболее активно этот процесс протекал вдоль магистральных каналов движения гидротерм, которые маркируются сильным окварцеванием в кавернах и порах. Самое глубокое перерождение при этом испытали органогенные (фитогенные) и органогенно-обломочные доломиты. Связано это, в первую очередь, с чистотой химического (минерального) состава и хрупкостью пород. В таких породах все преобразования, вызванные необходимостью перехода в новое состояние, устойчиво существующее при более высоких значениях температуры и давления, могут идти до конца. Именно поэтому наиболее высокопродуктивными оказались скважины, пробуренные в пределах дезинтегрированных, насыщенных кремнистым материалом фрагментов рифоподобных строматолитовых построек в различных рифей-вендских литолого-стратиграфических комплексах ЮТЗ [8].

Растворы циркулировали не только по разломам и участкам оперяющей трещиноватости. Они активно распространялись по поверхности регионального несогласия, разделяющей рифейские и вендские образования, и вовлекали их в активное перерождение. Так, по данным А.М. Пустыльникова и Л.Г. Вакуленко [14], процесс окремнения, положительно влияющий на приобретение породами вторичных фильтрационно-ёмкостных свойств, прослеживается на глубину первых десятков метров вверх по разрезу от контакта с отложениями рифея. Эти факты объясняют главные причины возникновения единого венд-рифейского резервуара Байкитской антеклизы.

\section{Заключение}

В процессе исследований было установлено следующее.

1. Формирование единого венд-рифейского резервуара ЮТЗ произошло в результате гидротермальной деятельности, которая наиболее активно проявилась в триасе и была связана с трапповым магматизмом.

2. Гидротермальные изменения карбонатных толщ при окварцевании (окремнении) и кавернообразовании носят отчётливо выраженный зональный характер: исходные доломитовые породы $\rightarrow$ перекристаллизованные доломиты $\rightarrow$ анкериты $\rightarrow$ кварцевые тела.
3. Вторичные (перекристаллизованные) доломиты и анкериты формировались в результате воздействия горячих растворов, одновременно обогащённых $\mathrm{Fe}, \mathrm{Si}$ и другими элементами, а также УВ-флюидом, на толще доломитовых пород в обстановке почти закрытой системы с повышенными температурами. Можно уверенно предполагать, что это вызывало синхронное образование в карбонатных породах трещинно-каверновых (трещинно-порово-каверновых) коллекторов и их насыщение УВ.

4. Прогноз перспективных на нефть и газ площадей в венд-рифейских отложениях ЮТЗ базируется на выявлении зон активной гидротермальной деятельности, приведшей к появлению каверн и пор (высокоемких коллекторов) в трещиноватых карбонатах. Минералами-индикаторами нефтегазонасыщенных доломитов являются анкериты, ассоциирующие с кварцем.

\section{Библиографический список}

1. Сурков В.С., Коробейников В.П., Крылов С.В. и др. Геодинамические и седиментационные условия формирования рифейских нефтегазоносных комплексов на западной окраине Сибирского палеконтинента // Геология и геофизика. 1996. Т.37, №8. С.154-165.

2. Харахинов В.В., Мухаметзянов Р.Н., Соколов Е.П. и др. Перспективы открытия крупных и уникальных скоплений углеводородов на западе Сибирской платформы // Приоритетные направления поисков крупных и уникальных месторождений нефти и газа. М., 2004. С.126-136.

3. Конторович А.А., Конторович А.Э., Кринин В.А. и др. Юрубчено-Тохомская зона газонефтенакопления - важный объект концентрации региональных и поисковоразведочных работ в верхнем протерозое Лено-Тунгусской нефтегазоносной провинции // Геология и геофизика. 1988. №11. C.45-56.

4. Конторович А.Э., Изосимова А.Н., Конторович А.А. и $\partial p$. Геологическое строение и условия формирования гигантской Юрубчено-Тохомской зоны нефтегазонакопления в верхнем протерозое Сибирской платформы // Геология и геофизика. 1996. Т.37, №8. С.166-195.

5. Бакун Н.Н., Копилевич Е.А., Давыдова Е.А., Соколова Н.Е. Литогенез и спектрально-временная характеристика типов разреза рифейских отложений Куюмбинского месторождения // Геология нефти и газа. 1999. №9-10. С.57-64.

6. Славкин В.С., Зиньковский В.Е., Соколова Н.Е., Давыдова E.A. Геологическая модель рифейского резервуара Куюмбинского месторождения // Геология нефти и газа. 1999. №11-12. C.13-21.

7. Харахинов В.В., Нестеров В.Н., Соколов Б.П. и др. Новые данные о геологическом строении Куюмбинского месторождения Юрубчено-Тохомской зоны нефтегазонакопления // Геология нефти и газа. 2000. №5. С.12-20. 
8. Мухаметзянов Р.Н., Соколов Е.П., Шлёнкин С.И. и др. Строение рифейских природных резервуаров Куюмбинского и Терско-Камовского участков Юрубчено-Тохомской зоны нефтегазонакопления // Геология нефти и газа. 2003. №4. С.39-45.

9. Шахновский И.М., Копылова О.Ю. Формирование месторождений нефти и газа, связанных с зонами перерывов в осадконакоплении // Геология нефти и газа. 1999. №5-6. C.22-27.

10. Чернова Л.С. Литогенетическая модель нетрадиционных карбонатных коллекторов рифея Юрубчено-Тохомской зоны (Восточная Сибирь) // Нетрадиционные коллекторы нефти, газа и природных битумов. Проблемы их освоения: Материалы науч. конф. Казань, 2005. С.327-330.

11. Сахибгареев Р.С. Привнос органического вещества в рифогенные известняки в процессе их доломитизации как причина сохранения коллекторов на больших глубинах // Закономерности размещения и критерии прогноза глубоких и сверхглубоких залежей нефти и газа. Л., 1982. C.122-133.

12. Арабаджи Е.М., Страхов П.Н. История формирования пустотного пространства в карбонатных отложениях Калинового месторождения // Геология, геофизика и разработка нефтяных месторождений. 1995. №5. С.15-17.

13. Коробов А.Д., Коробова Л.А. Гидротермальные процессы в погребённых палеорифтах Западной Сибири и их роль в доломитизации известняков и насыщении пород фундамента нефтью // Геология нефти и газа. 2005. №3. C. $37-46$.

14. Пустыльников А.М., Вакуленко Л.Г. Происхождение и формы выделения кремнезёма в рифейских отложениях Байкитской антеклизы (Сибирская платформа) в связи с проблемой формирования трещинно-каверновых коллекторов // Геология и геофизика. 1997. Т.38, №12. С.19621967.

15. Гришин М.П., Старосельиев В.С., Сурков В.С. и др. Мегакомплексы и глубинная структура земной коры нефтегазоносных провинций Сибирской платформы. М., 1987. $132 \mathrm{c}$.
16. Эикин В.Ю. Гидротермальные изменения карбонатных пород около хрусталеносных жил // Зап. Всесоюз. минералог. о-ва. 1963. Ч.ХСІІ, вып.1. С.3-14.

17. Эикин В.Ю. Об источниках минералообразующих компонентов на примере одного из хрусталеносных месторождений Приполярного Урала // Зап. Всесоюз. минералог. о-ва. 1964. Ч.ХСІІІ, вып.6. С.672-681.

18. Бочкарёв А.И. Об образовании кварцевых тел и хрустальных гнёзд в карбонатных породах // Зап. Ленингр. горного ин-та. 1965. T.XLIX, вып.2. С.139-148.

19. Соколов Б.А., Мазор Ю.Р. Нефтегазоносность бассейнов древних платформ и трапповый магматизм // Вестн. Моск. ун-та. Сер.4, Геология. 1980. № 6. С.53-59.

20. Конторович А.Э., Хоменко А.В. Теоретические основы прогноза нефтегазоносности осадочных бассейнов с интенсивным проявлением траппового магматизма // Геология и геофизика. 2001. Т.42, №11-12. С.1764-1773.

21. Коробов А.Д. Гидротермальный литогенез в областях наземного вулканизма: Автореф. дис. ... д-ра геол.-мин. наук. М., 1995. 44 с.

22. Соколов Б.А., Абля Э.А. Флюидодинамическая модель нефтегазообразования. М., 1999.76 с.

23. Готтих Р.П., Писоикий Б.И. Роль эпитермальных флюидов в первичной миграции углеводородов в осадочном чехле Сибирской платформы // Первичная миграция и нефтегазоносность осадочных бассейнов. М., 1988. С.4756.

24. Мигурский А.В., Старосельиев В.С. Зоны разломов естественные насосы природных флюидов // Отеч. геология. 2000. №1. С.56-59.

25. Коробов А.Д., Коробова Л.А., Киняева С.И. Гидротермальные процессы в палеорифтах Западной Сибири и их роль в формировании жильных ловушек УВ доюрского комплекса Шаимского района // Геология, геофизика и разработка нефтяных и газовых месторождений. 2004. №12. C.63-72. 